\title{
A fifteenth-century fencing tournament in Strasburg
}

Olivier Dupuis, independent researcher

\begin{abstract}
An undated paper from the archives of Strasburg contains a set of rules approved by fencing masters for a fencing tournament. The dating of this document is uncertain but could be established around 1470-71. A complete and unpublished transcription will be supplied and completed with a detailed study of the final set of rules but also the subset which received some modifications. Even if some key points remains obscure, it's possible to find some comparison between this text and the contemporary knightly tournaments or the German Fechtschulen. Keywords - fencing, rules, tournament, Strasburg
\end{abstract}

Thanks to chronicles, poems and details found in fencing treatises, fencing events for commoners in the Holy Roman Empire of the sixteenth and seventeenth centuries are well documented (Schauer 1901). Unfortunately, the documentation is far more limited for the fifteenth century, especially before the imperial privilege accorded to the fencing guild of Saint Mark in 1487 (Schmied-Kowarzik, Kufahl 1894:110-113). Nevertheless, a few accounts remain which prove that such events had occurred before, for example in 1397 in Frankfurt (Baader 1866:480) or 1444 in Rothenburg (Schubert 1995:241) and more frequently after 1460 (Jaquet 2012). In this context, the following regulation for a fencing event organized, or at least supported by, the city of Strasburg is an indisputable contribution to the history of fencing.

\section{PHYSICAL DESCRIPTION}

The document is a single page of paper with writing only on one side, and bound and archived as number 182 in the folder $1 \mathrm{MR} 13$ in the archives of the city and urban community of Strasburg (ACUCS). Following the classification order this folder gathered undated regulatory documents from the fifteenth century; Mariotte claimed that it had been built up as soon as the seventeenth century and bound and indexed as early as mi-eighteenth century (2001:75). During the binding or the indexation process, a seventeenth- or eighteenth-century archivist wrote a brief summary on the top of each document in the folder. The one which interests us received the few word Ordnung des Fechtens; all other writing is in a fifteenth-century hand. The first paragraph of text is a list of patricians of the city, and the remaining texts are the rules themselves. Many corrections have been made to the text, including paragraphs added at a later date and words crossed out, with replacement text inscribed above the line. These corrections, as well as the lack of any title or clear dating information, could mean that this document was not the final version, but instead an intermediate working document. I will develop this theory further below. 


\section{TRANSCRIPTION}

Thanks to clear variations in the ink, it can be asserted that the document was written in two phases, perhaps by the same scribe. The first version had been modified in many ways:

- groups of words crossed out $(\$ 2)$

- insertions of sentences above the lines $(\$ 2$ and $\$ 10)$

- insertion of a sentence in the margin $(\$ 2)$

- $\quad$ insertion of new paragraphs $(\$ 3, \$ 6, \$ 8, \$ 11)$

It is not possible to know exactly when the edits were made, but a sentence added to the third paragraph asserts that the signatories wished some modifications to the original text. The additions could even being made on the same day as the other text, as the only calendar information found in the text has not been modified ( $\$ 2$ : "morn zinstag"). It has been possible to transcribe what could be seen of the first version of the second (Appendix 2), and last paragraphs (Appendix 1), which allows us to see what modifications were made to the text.

The structure of the text is, in broad strokes, as follows:

1: Members of the magistrates, signatories

$\$ 2$ : Schedule of the bouts, conditions for losing each bout, condition for winning the prize

\3: Notification of modification

$\$ 4$ : Obligations of the city

\5: Crowd control

86: Security rules for people entering the field

57: Organization of the jury

\$8: How to stop a bout

\9: Recording management

§10: Public regulation

\11: Additional security rules for the bouts

\section{PREVIOUS EDITION}

This text has already received a preliminary, but only partial transcription, by an historian of Strasburg as a brief endeavour along his massive work on everyday life in fifteenth-century Strasburg (Hatt 1929:406 and 470). Hatt's main interest was to mention the existence of fencing events as an example of the many leisure activities of that time, which could explain why he omitted certain paragraphs $(\$ 3-5, \S 8$ and $\$ 11)$ and one sentence (in \$2), which had no relevance to his study. This certainly justifies another transcription. 


\section{DATING THE TEXT}

The first paragraph mentions the four lords from the Magistrate of Strasburg who had validated the following text: Friederich Bock, Jacob Amlung, Claus Baumgarter and Bernhart Bock. These four signatories all participated to the city management at various times during the second half of the fifteenth century. Even if their dates of birth, baptism or death are mostly unknown, a few biographical details are known about them and aid in the dating of the text. However, it is first necessary to discuss the management of the city and their responsibilities a bit more deeply.

Briefly, Strasburg became an imperial city under the sole authority of the Emperor in the thirteenth century. At the end of the fifteenth century, the city was a prosperous and strong cultural center in the Empire. It had a stable constitution which instituted (Brady, 1978:163-168):

- Two privy councils actually governed the city, whose participants are mostly permanent residents

- The Senate (Rat), which sat as a court of law, was elected for two years terms and consisted of ten representatives of the patricians (Constofler) and one representative per trade guild

- The municipal magistrates from the Senate elected a burgomaster (Ammeister) each year. He could not be re-elected for the next five years, but could serve as "former burgomaster" (alt Ammeister) to one of the Privy Councils.

- The patricians from the Senate elected four vice-burgomaster (Stettmeister) from the noble families for two-year terms

- The Senate and Privy Councils (Rat und XXI) were appointed by the burgomaster.

Friederich Bock belonged to an old family of small nobility from Strasburg which can be documented as far back as the beginning of the fourteenth century. The first mention of him is dated to 1454 (Chartier de Niedernai:348). He participated to the battle of Seckenheim (1462) and was elevated to the rank of knight (Chartier de Niedernai:391). He was also the former burgomaster Peter Schott's second-in-command when the latter led the militia of Strasburg at the battles of Morat (1475) and Granson (1476), where he probably got his unexplained nickname Sturmfeder, literally "Thunderfeather" (Kindler of Knobloch 1886:39). After the Burgundian wars, Bock hoped to participate to the imperial tournament at Wurtzburg (1479), but the rules enacted in Bamberg in 1478 forced him to prove that he or his parents had attended a tournament of equivalent prestige during the preceding fifty years. He probably couldn't do this, and placed his hope in the second part of the rule that "without evidence, witnesses could be enough for the next Tournament" (Rühl, 1990:168) and in 1480 sought and found witnesses from his family (Chartier Niedernai:459, 462, 463, 468). Unfortunately for him, the rules were improved for the next imperial tournament of Heidelberg (1481), which forbade burghers from participating (Rühl 1990:173-174). Merely being a knight was not enough (Morsel 1993:313-317) to 
consort with the high nobility in Germany at the end of the fifteenth century. He was elected for a two-year term as representative of the nobles to the Senate in 1470, which began a long period of public responsibilities for him. Beginning in 1474, he was regularly designed as Stettmeister (1474-75, 1477-78, 1480-81, 1483-84, 1486-87, 1490, 1492-93, 1495-96, 1498-99, 1501-02, 1504-05, 1507) which made him one of the most important public people in Strasburg at that time (Hatt 1963).

Bernhard Bock, a squire (Edelknecht) was not directly related to Friederich, but both were from the same old noble family. He was cited in a document as early as 1423 (Kindler von Knobloch 1886:39) and was elected to represent the Constofler in the Senate in 1453, 1458-59, 1462-64, and 1470-71. Incidentally, on the 30 $0^{\text {th }}$ of June 1480, he gave written testimony on Friedrich's behalf that a common ancestor, Cunz Bock, had participated to a tournament (Chartier de Niedernai:462).

Claus Baumgarter came from a rich family and was elected as the municipal magistrate from the trade guild of innkeepers in 1444, 1450, 1456, 1461-62, 1469-70, 1475-76, and 1489. He was co-opted to enter the privy councils of the XIII in 1463 (Brady 197:385), and most importantly, was elected by the Senate as burgomaster in 1466, 1472, 1478, and 1490 (Hatt 1963), which implies a terminus ante quem for the event as 1467 , the first year Baumgarter became alt ammeister.

Jacob Amelung had the same profile as Claus Baumgarter and was elected as municipal magistrate from the craft guild of boatmen in 1455, then again from the Constofler in $1460-61$, and from the craft guild of coopers in 1466-67, 1472-73, 1478-79, 1484-85, and 1490-91. He probably left the Constofler guild for the Coopers to become eligible to the office of burgomaster, which occurred in 1463, 1469, 1475, 1481, 1487, and 1493 (Hatt 1963). He died in 1495 (Kinder von Knobloch:13), which is at least the terminus post quem for the event.

This document was stored into a folder of rules from the magistrates of the city of Strasburg, which mean that the four signatories should have all been magistrates. The only possibility for this is the period of years 1470 and 1471, when both Bernhard Bock and Friederich Bock were representatives of the patricians. Claus Bömgarter and Jacob Ammlung were both former burgomaster and were either members of one of the Privy Councils,or received a delegation from the burgomaster to validate the text.

One discrepancy is "Jacob Amlung, Claus Bömgartner Alt Ammeister". Amlung became burgomaster before Baumgarter and was either former burgomaster or burgomaster until his death. But in the latter case, it should have been mentioned, and then this sentence might perhaps be understood "beiden Alt Ammeister."

\section{A SECOND EVENT}

Hatt assumed that another archived documents from the fifteenth century dealing with a fencing tournament (ACUCS 1MR369) concerned the same one (1929:406). The second document is also undated and does not have any signatory name written. The 
main concern of this text is a horse race which took place in the morning of the Saint Ulrich's day, normally the $4^{\text {th }}$ of July. In the upper and left margin of the document, a few lines were inserted about a fencing event. Two copies of this text also existed in another folder in the archives (ACUCS AA1921 documents 1 and 8), both seem to have been the tidy version of, respectively, the horse race rules and the fencing tournament and do not bring more information. The fencing tournament was a fencing show where both fencing masters and students were accepted and had to fence all together in mêlée to share an overall prize: "den schirmermeistern und schulern etlich goben vsgeben wellent darumb zu vechten, in massen als dann das eigentlich usz geschriben ist, do sol menglich wissen..." (Hatt 1929:468-469). This is clearly a completely different format that the one studied here and they are definitely two separate events.

\section{FACILITIES}

The barriers (schranken) circumscribed the place where the bouts took place $(\$ 2, \S 5-6)$; their presence was hardly surprising as they were common installations to separate the combatants from the public and the judges in tournaments or pas d'armes. For instance, René d'Anjou, in his treatise on the tournament (Quatrebarbes 1859:15-16) gave many details on how the barriers should be deployed. For that event, the text does not mention their construction. They therefore might have already been in place, either at the city's expense or that of another party. Evelyne Van Den Neste, in her study of the tournaments in Flanders recorded in city accounts, showed also that such facilities were rarely at the expense of the city organizing the event (1996:80-81). However, to come into the barriers was also used as an euphemism for going to have a judicial fight, as Hans Talhoffer wrote: "wenn er nun gelert ist und in den schrancken sol gon" (1459:f10r). This was of course not the case here, but one can see the similarity between fencing events, knightly tournaments, and these types of duels.

The description of the platform, (fuess bunnen), is a little more detailed: it must be built for the occasion and correctly nailed $(\$ 5)$. It must be placed beside the barriers in such a way the sun wouldn't interfere. This last detail clearly indicated that this facility was intended for distinguished guests to view the bouts, probably for the judges or any other prominent citizens. Here also, a parallel can be found in the tournaments of Flanders where the platforms were placed depending on the quality of the view (Van Den Neste 1996:80-81), or in one record of Olivier de la Marche of a tournament which happened in 1469 where the ladies were seated on a platform at one side of the field: "lesdites damoiselles auront leur eschafault sur les rencz" (Prost 1878:62).

\section{SITE}

The text does not give any clue where the barriers were installed. As mentioned before, Hatt assumed that it took place in the horse market area, a large open area along the north wall of the old Roman fortification, included during the thirteenth century into a larger defensive wall. It could have very well been at this place, the vaster in the city, which received the two last knightly jousting tournament held in Strasburg, in 1418 and 
1507 (Welschinger 1908:94). But other places could be equally good candidates, as the one in front of the city hall, which was also a common place for tournaments in Flemish cities (Van Den Neste 1996:67-68), but also the corn market which is pictured in the oldest map of Strasburg with permanent barriers (Châtelet-Lange 2001:122).

\section{EQUIPMENT}

The third paragraph informs that the city will provide enough swords and staves. These swords are undoubtedly the ones that would be used in the bouts and are most probably unsharpened, as was the standard for tournament in the Holy Roman Empire (Rühl 1990:170) or in the rules of René d'Anjou (Quatrebarbes 1859:12). In such events for the chivalry, the participants usually carried their own swords, whose specifications are given in detail. However, some chronicles of pas d'armes also mention that the weapons were provided by organizers: "par iceulx leur sera baillié deux lances et deux espées" (Prost 1878:62).

The staves are also mentioned in another paragraph $(\$ 8)$ where it is stated that they will be used to help the judges to stop the combatants.

The participants could carry real weapons, such as knifes, in their daily lives, but must let them leave outside the barriers $(\$ 6)$; the word used, gelbere, was a generic word which could meant either "weapons" or "protections," and this was the sense Hatt used for his interpretation. However, this is exactly the same word used to prohibit weapons carrying in Strasburg for workers in 1474: “...das kein antwerck knebt tëgen oder scheide lenger dann die mosse, ouch keyn exel, bibel, kolben noch dehein ander gewere..." (Hatt, 1929:448). In this context I hypothesize that it is only intended to weapons; to my mind this is clearly a security rule which finds parallels in chivalric tournament rules where no other weapons than the approved ones could be carried (Rühl 1990:170).

\section{AUDIENCE OBLIGATIONS}

An entire paragraph is dedicated to the audience's obligations (\$11), mostly to avoid disorder during the event and to respect the fencers. It was forbidden to shout or to laugh at the fencers, to spit out or to throw stones or any rags at them. The punishment was a fine of thirty shillings or one month of imprisonment if one could not pay. The amount of this fine seems very huge as it was equivalent to dozens of salary weeks for a common tradesman (Zimmermann 1971:51). However, there is nothing surprising here: This amount was in accord with the standards of the city of Strasburg each time they wanted to dissuade any troubles (Hatt 1929:114) and similar injunctions were given to the audience of the horse race I have already mentioned. I understand them as precautions taken by city, which took on the responsibility of the organization, to protect their image. 


\section{PARTICIPANTS}

The combatants of the event were categorized as masters or students (meister und schuler). Both professionals and amateurs were accepted as participants in the event $(\$ 6, \S 9)$, as the word scbuler should be understood as someone who is not a master himself.

\section{ARBITRAL BODY}

The arbitral body was composed of the four grieswarter, assisted by two fencing masters. The grieswarter - literally, the "grit-warder" — didn't appear in tournament contexts, but was the word used to refer to the referee in judicial duel (Kellet 2008:49). Talhoffer also uses this term in the mid-fifteenth century in the same context; the grieswarter was chosen here by the judge ("[der richter sol] in ainen ring machen und grieß wartten und urttail geben", 1459:f9r), he accompanied the combatants in the ring and have to pay heed to the judge ("Der maister und die grieß wartten söllend mercken uff den richter...", 1459:f10v). In this event, the signatories were unambiguously appointed to be the grieswarters $(\$ 2)$; the two fencing masters are probably selected from the ones who were consulted to approve the rules. However, the text clearly mentions that one fencing master must be local and the other from a foreign land, probably so as not to be blamed for biased judgments. This is comparable to the rules of René d'Anjou, where he stated that the lord holding the tournament must select half the judges from the land of the defending lord, and the other two from his own land or from any other place ("ledit seigneur appellant doibt toujours eslire des juges la moittié: c'est assavoir, deux du pays du seigneur deffendant, et les autres deux de son pais on d'ailleurs a son plaisir", Quatrebarbes 1859:3). These two fencing masters were to help the grieswarters judge the hits and to make sure that the warding of hits and the highest wounds was done properly (\$7). Those six mentioned judges are divided into two groups, probably stationed in two separate places on each side of the barriers, though it is not clear whether they were to stay inside or outside the barriers. Normally, the grieswarter stood inside the barrier with his staff, and here the judges also have staves to thrust or lay their own staff between the combatants, which could indicate that the arbitral body was to be inside the barrier.

The only ancillary official cited is a scribe who was to register the combatants and to record the hits $(\$ 9)$ and their location, or at least their height. This could be compared to the English scoring system used in jousting tournaments, which also required the recording of hits on special forms, or "cheque lists" (Rühl 2006).

\section{STRUCTURE OF THE TOURNAMENT}

The main part of the document $(\$ 2)$ details how to manage the tournament: how the fencers were to be paired up, how they were to progress towards the final result, and what the conditions were to receive the prizes.

The first question to be resolved was how to match up the fencers. The text clearly states that this question was remanded to a future meeting with the signatories and the fencing masters to be held the following morning. The choice was between having 
fencers paired at random, or letting them ask to fence one another as they went along. The first version of the text was quite clear on that subject : "einer an den anderen ordenen vnd lesche oder wellent vmb die ofentuoren zu vechten oder obe sie gemeinlich durch einander vechten wellent" - but the word "ofentuoren" might have not been satisfactory, and the first part of the proposition was replaced with the following: "obe sie das lossen werffen wellent jn dem schranken sin gestelle vmb das vechten also daßjr zwen vnd zwen zuisammen kommen vnd welche dann mit dem loß zu sammen kommen mit einander zi vechten..." This can be translated as, "if they wished to draw lots to determine their place inside the barriers for the bouts, since they were to fence two by two, then those who have to fence together should come to draw lots together." The word gestelle, only used once, is difficult to correctly understand in this context. Does it mean that the two fencers who were not equal and a particular place was more interesting than another? Most probably it means the place in the tournament.

The second step was to determine how the fencers would progress towards the final result. The two combatants drawn by lots would have only one chance ("ein₹ moles vechten") with the one being struck having to leave while the victor stayed ("wer je geslagen wurt ab zi gon und ein ander an die statt"). Would the winner of the bout stay into the barriers and have to fence again, or does this mean that he would merely stay in the contest and have to wait to be selected with another fencer? The first option means that the one who lost could have another opportunity to compete another time in the tournament, while the winner would stay in place so long as nobody beat him. The second option would seem to indicate that this tournament used a single elimination format.

As noted above, a bout finished at the first hit. However, it seems to not have been easy to see, as fencing masters were required to help the grieswarter to detect them $(\$ 7)$. Also, as described above, a scribe would note the height and who made it. The word "blütrur" could be translated as a bleeding wound, but could also be understood as a wound that marks the body. In some demonstration fencing matches organized at the court of the castle of Stuttgart on March 12, 1596, the chronicler noted that the duke explained to the participants that a hit must cause a visible red mark or make blood flow to be valid: "es mießte rot oder blut geben, sunst gelt es nip" (Fechter 1840:208). The statutes of the fencing guild of Amiens from 1530 have a similar category of wounds: "qu'il luy face rose ou sang" (Augustin 1853). Depending on the gravity of the wounds, a combatant could have been obliged to stop his participation (\$11).

The rules are not clear on how the tournament would go on. In a hypothetical single elimination format, the end would be quite easy to deduce. In the other hypothesis, a fencer could try his luck many times, but probably not against the same opponent as it would have been considered as a second chance. Moreover it's easy to imagine that someone loosing many bouts would quickly have too many wounds to continue. The tournament would have been finished naturally when the last winner won against every remaining fencers or when nobody wanted to face him. 
The prizes were given to the two fencers who achieved the highest and most bleeding wounds ("meisten und böhsten blütrüre"); this seemed to have been standard at that time. Similar criteria appeared in a French source from the first half of the sixteenth century: "Et pour gaigner le jeu de pris... le plus baut coup est le plus beau." In France, a poem from the first half of the sixteenth century described many rules for the practice of fencing and likewise declared that the highest touch was the most beautiful: "Le plus hault coup est le plus beau" (Letainturier-Fradin 1904:78-91). In 1575, Fischart, a novelist who lived most of his life in Strasburg, described fencers who fought for the highest bleeding wounds in one if his novels: "focht umb die böchst Blutrubr" (Fischart 1963:275); this word, Blutrubr, seemed to have been a technical term.

The adjective "meisten" could be understood as the most, which does not make sense for a single-elimination format, as the winner would be the one who won the last bout. In the other hypothesized tournament structure, the criteria could be understood as the two combatants who combined the most bouts won with the highest hits. This is a strong argument in favour of this hypothesis, and to me it was decisive. The only format of tournament that could share all of the constraints could be, to sum up:

- In each bout, the first fencer who hits wins the bouts and stays, the other leave and could try again if the wound received allow him to do so.

- Another participant, chosen by chance or a volunteer, depending on the decision of the fencing masters, enters the barriers to fence against the last winner

- The first pair of fencers are selected also by chance or volunteering

- The tournament ends when either no one wants to fence against the last winner or when every fencers remaining have already lost against him

\section{AMBIGUOUS SENTENCES}

The last sentence of the second paragraph remains obscure: "vnd welhes sie de gemeinlich vff nemen es doby lassen zu bliben." It could mean that anybody who would like to continue could stay, but this is uncertain. It could also refer to the meeting mentioned at the beginning of the paragraph and conclude that whatever the fencing masters decide together has to apply.

\section{DIFFERENCES BETWEEN THE FIRST AND FINAL VERSIONS OF THE TEXT}

My study of the content is only concerned with final version. However, it is interesting to look at the improvements added to the initial text, and especially at how the categories of rules evolved. The additions mainly concern the security of the fencers, such as forbidding the wearing of weapons inside the barriers (\$6), giving the possibility of stopping participation in the tournament in case of wound $(\$ 11)$ and specifying that a bout should stop after one of the judges have pushed their staff between the combatants ( $(8)$. 
The modifications to the second paragraph are substantial and concentrate on clarifying the organization of the bouts. It is not clear whether these modifications were made after the meeting with the fencing masters, scheduled for the day after the first version of the document, or before, after proofreading. The text claiming that a meeting with the fencing masters would have to take place hasn't been modified, which is a good argument in favour of a proofreading before the meeting. However, the text remains in a raw form, and the corrections did not give an answer to the question suspended until the meeting, which is strong argument for it having been made during the correction of the document before the meeting. However, it's impossible to know if a real final version of the rules ever existed.

\section{COMPARISON WITH THE FENCING SCHOOLS}

In the fifteenth century, the terms schirmschule and fechtschule referred to fencing events, held by a fencing master with the authorization of the local authority but the earlier known regulation texts dated from the sixteenth century, as the "Augsburgische Fecbter Ordnung" (Dupuis 2009:7-15). In the same period in Strasburg, the fencing masters themselves took the entire responsibility for their organization, from the source of funding to the advertising; the magistrates only retained the power to refuse any unusual activity in the public spaces (Dupuis 2006:109-110). Then could this event be considered as a German fencing school? Probably not, as none of the terms schirmschule and fechtscbule were used, and the involvement of the city of Strasburg in this event was strong and unambiguous.

\section{CONCLUSION}

This fencing event could not be considered primitive; on the contrary, the rules, contained therein are elaborate, even if they did not match any other types of tournament format known during the period. Making due allowance, this event shared many similarities with the ceremony for jousting: weapon regulation, facilities, use of a scribe to register the participants and note the results, and involving a foreign master in the arbitral body. But the knightly tournament was not the only reference used. For instance, the words "grieswarter" or "blütrüre" were direct references, respectively, to judicial duels and fencing. There is very little information as to the popularity of fencing at this time, but it could be supposed that it was important enough to encourage the magistrates of Strasburg to sponsor and manage an public event in order to increase the renown of the city, as it was mentioned in the beginning of the text, "der Statt qu eren".

The fact that the city took in charge the organization of this event gives us a great opportunity, as it caused the creation of a document preserved in the city archives. Though certainly other forms of rules for fencing tournaments were used in the fifteenth century, or even earlier, in the Holy Roman Empire, but the archives remained largely unexploited, and there is reasonable hope of finding other pearls in the future. 


\section{APPENDIX 1: TRANSCRIPTION OF ACUCS 1MR13 182}

Corrections are in italics.

\$1 Her friderich bock Ritter her Jacob Amlung her Claus bömgarter Alt Ammeister vnd bernhart Bock

\2 Item díe hant gerotslaget das man der Statt zů eren vnd Noch Rede zů entberen vff morn zínstag alle frömde vnd heimschen schírmeistere besende fưr die egenanten vier herren díe gríeswarter vnd jn díe wale zů gebe, obe sie das lossen werffen wellent jn dem schranken sin gestelle vmb das vechten also daß jr zwen vnd zwen zůsammen kommen vnd welche dan $n$ mit dem loß zů sammen kommen mit eínander zů vechten obe sie gemeinlich durch eínander vechten wellent, doch das Jr zwen allein einz moles vechten die also mit dem loß zůsammen geůallent vnd wer jr geslagen wurt ab zů gon vnd eín ander an díe statt vnd wer dan $n$ also díe meisten Vnd die höhsten blütrüre geton hett dem solt sín gobe gedihen desglichen den andern darnach vnd welches sie de gemeínlich vff nemen es doby lossen zů bliben

§3 hant gewellen trehlen die herren

\4 Item das die Statt gern eyne slberte darlenge desglich stangen gnüg

\5 Item den platz jm schrancken mit einersatten füß bůnen zů machen díe vff dem grunde stät vnd vff Ríemen genegelt sỷ vnd díe zů machen an das ort das man dan $n$ bescheiden wurt vnd es aller füglichst ist der sonnen halp

\$6 Item das ouch alle meisterer und schůler so jn den schrancken kommen vechtens halp

alle jr gelbere von jren tůn vnd vßwendig des schrancken zů lassen

\$7 Item zwene schírmeister zů nemmen eínen von den frómden vnd eínen von den heímschen díe do by den herren standen nemlich vff jeder siten by jr zwein herren eíner die helffen sehen vnd warnemmen vff díe Rüren das das Redelich vnd uff recht zůgange

\8 Item wann díe vier gríeswarter eíner oder der schírmeister eíner so beyden herren stende

die stange noch dem Rüre zweischen síe stosset oder leyt so sol keyner keyn streich zůtůn sol nit geben

\9 Item eínen schriber do zů haben díe meister und schůler anzůschriben vnd ouch wer die höhsten und fryesten blütrüre tüge

\10 Item eín gemein offen gebott zů tün allen menschen junge vnd alte vff solichen tag vnd stund so dz vechten geschicht kein vnfür zů triben vber die schírmer zů lachen zů schringen oder jr zů spotten, ouch dehein vnfür zů triben mit lumben stein oder bocht werffen by $\operatorname{xxx} \beta \delta$ oder by eim monat jn turn der dz gelt nit zů geben hat

\11 ouch welhen ein Růre wurt der sol nit verbunden sin mit genge vưrün er tüge es dann gern 


\section{APPENDIX 2 - ACUCS 1MR13 182 TRANSCRIPTION OF THE FIRST VERSION OF THE SECOND PARAGRAPH}

Item díe hant gerotslaget das man der Statt zů eren vnd Noch Rede zů entberen vff morn zínstag alle frömde vnd heimschen schírmeistere besende fůr die egenanten vier herren díe gríeswarter vnd jn díe wale zů geben obe síe líeber Je einer an den anderen ordenen vnd lesche oder wellent vmb die ofentuoren $\mathrm{zu}$ vechten oder obe sie gemeinlich durch eínander vechten wellent, doch das jr zwen allein einz moles vechten vnd wer jr geslagen wurt ab zů gon vnd eín ander an díe statt vnd wer dan $n$ also díe meisten $V$ nd die höhsten blütrüre geton hett dem solt sín gobe gedihen desglichen den andern darnach vnd welches sie de gemeinlich vff nemen es doby lossen zů bliben

\section{REFERENCES}

Augustin T. (1858). Recueil des Monuments Inédits de l'Histoire du Tiers État. Serie 1, Vol. 2. Paris: Firmin Didot frères. pp.584-588.

BAADER J. (1866). Ordnung der Federfechter zu Prag. Jagd-Zeitung, 9, pp.480-482.

BRADY T. A. Jr. (1978). Ruling Class, Regime and Reformation at Strasbourg 1520-1555. Leiden: E. J. Brill. 458p.

Chartier de Niedernai (2000). 1. Strasbourg: Région Alsace.

Châtelet-Lange L. (2001). Strasbourg en 1548 : le plan de Conrad Morant. Strasbourg : Presses Universitaires de Strasbourg. 163p.

Dupuis O. (2006). Joachim Meyer, escrimeur libre, bourgeois de Strasbourg (1537 ? - 1571). In Maîtres et techniques de combat. Dijon: AEDEH, pp.107-120.

DupuIS O. (2009). Transkription der Handschrift I.6.2.5. [WWW] Gesellschaft für pragmatische Schriftlichkeit. Available from : http:// www.pragmatische-schriftlichkeit.de/transkription/ Cod.I.6.2.5. 16.03.09.pdf [Accessed 05/04/2013]

Fechter D. A. (1840). Thomas Platter und Felix Platter zwei Autobiographieen. Basel: Seul und Mast. 208p.

JAQUET D. (2012). Entre éducation et festivité: Schirm- und Fechtschulen dans l'ancienne Confédération suisse, XVe-XVIe siècles. Meuwly, O. ; Guex, N. Duel et combat singulier en Suisse romande: de l'Antiquité au XXe siècle. Bière: Cabédita, pp.77-87.

FISCHART J. (1963). Geschichtklitterung (Gargantua). Düsseldorf: Karl Rauch.

Hатт J. (1929). Une ville du XVe siècle, Strasbourg. Strasbourg : Imprimeries des Dernières Nouvelles de Strasbourg. 507p.

HATT J. (1963). Liste des membres du grand Sénat de Strasbourg, des stettmeistres, des ammeistres, des conseils des XXI, XIII et de XV du XIIIe siècle à 1789. Strasbourg: Mairie. 677p.

KeLLET R. (2008). Single Combat and Warfare in German Literature of the High Middle Ages: Stricker's "Karl der Grosse" and "Daniel von dem Blühenden Tal". Leeds: Maney Publishing. 277p.

KINDER von KNOBLOCH J. (1886). Das Goldene Buch von Straßburg. 2d ed. Wien: Carl Gerold's Sohn.

LAHNER (1859). Zur Geschichte der Fechtschulen in Nürnberg. Anzeiger für Kunde der deutschen Vorzeit, 6. 408p. 
LetAinturier-Fradin G. (1904). Les Joueurs d'Épée à travers les siècles. Paris: Flammarion. 599p.

MARIOTTE J.-Y. (2001). Les sources manuscrites de l'bistoire de Strasbourg. Strasbourg: archives municipales de Strasbourg. 367p.

Morsel J. (1993). Le tournoi, mode d'éducation politique en Allemagne à la fin du Moyen Âge. In:

Éducation, apprentissages, initiation au Moyen Âge. Montpellier: Presses Universitaires, pp.309-331.

Prost B. (1878). Traicté de la forme et devis comme on faict les tournois par Olivier de la Marche, Hardouin de la Jaille, Anthoine de La Sale, etc. Paris: Barraud.

Quatrebarbes T. (1859). Oeuvres choisies du roi René. Paris: Edme Picard. 150p.

RÜHL, J. K. (1990). German Tournament Regulations of the 15th Century. In: Journal of Sport History, 17(2), pp.163-182.

RüHL, J. K. (2006). Hommes et femmes dans les tournois du Moyen Âge. CLIO, 23, pp.15-43.

Schmied-Kowarzik J., Kufahl H. (1894). FECHTBÜCHLEIN. Leipzig: Philipp Reclam. 268p.

SCHUBERT E. (1995). Fahrendes Volk im Mittelalter. Bielefeld: Verlag für Regionalgeschichte. 497p.

Talhoffer H. (1459). Alte Armatur und Ringkunst. National Library of Denmark, Thott $2902^{\circ}$.

VAN DEN NeSTE E. (1996). Tournois, joutes, pas d'armes dans les villes de Flandre à la fin du Moyen Age (1300-1486). Paris: École des Chartes. 411p.

WelsChinger H. (1905). Strasbourg. Paris: H. Laurens. 152p.

ZimMERMANN J.-R. (1971). Les compagnons de métiers à Strasbourg du début du XIVe siècle à la veille de la Réforme. Strasbourg: Librairie Istra. 144p. 